\title{
Parenting Styles and Academic Self-Efficacy Beliefs of Omani School and University Students
}

\author{
Said S. Aldhafri ${ }^{1,2, *}$, Marwa N. Alrajhi ${ }^{1}{ }^{\circledR}$, Hussain A. Alkharusi ${ }^{1}{ }^{\complement}$, Ibrahim S. Al-Harthy ${ }^{1}$, \\ Hafidha S. Al-Barashdi ${ }^{3}$ and Amal S. Alhadabi ${ }^{3,4}$ \\ 1 Psychology Department, Sultan Qaboos University, P.O. Box 32, Muscat 123, Oman; \\ malrajhi@squ.edu.om (M.N.A.); hussein5@squ.edu.om (H.A.A.); ibrahimh@squ.edu.om (I.S.A.-H.) \\ 2 The Ministry of Higher Education, Scientific Research \& Innovation, Muscat 123, Oman \\ 3 Ministry of Education, Muscat 100, Oman; hafidhaalbarashdi@gmail.com (H.S.A.-B.); \\ aalhadab@kent.edu (A.S.A.) \\ 4 Foundation, Leadership \& Administration Department, Kent State University, Kent, OH 44240, USA \\ * Correspondence: saidaldhafri@gmail.com
}

Received: 13 July 2020; Accepted: 20 August 2020; Published: 2 September 2020

\begin{abstract}
The present study examined the predictive role of students' perceptions of parenting styles on their academic efficacy beliefs. This relationship was examined using two large sets of national data that were collected from school and university students to see how the relationship between parenting styles and academic efficacy beliefs may or may not vary across life stages. The sample included 1431 school students and 1119 university students cross the Sultanate of Oman. The participants responded to the Arabic version of the Parental Authority Questionnaire (PAQ) and to the Academic Self-Efficacy Scale (ASES) constructed by the researchers. Using linear regression model for each sample, the results showed that the amount of variance in school students' academic self-efficacy beliefs explained by parenting styles $\left(R^{2}\right.$ adjusted $\left.=0.21\right)$ was higher than the amount of variance explained for the university sample $\left(R^{2}\right.$ adjusted $\left.=0.10\right)$. The researchers concluded that the effects of parenting styles on students' self-efficacy beliefs decrease as children grow up.
\end{abstract}

Keywords: parenting styles; academic self-efficacy beliefs; school; university students; Oman

\section{Introduction}

Academic self-efficacy beliefs represent an important component of student motivation and they have an influence on students' academic achievement and school behavior [1-4]. These beliefs reflect the students' perceptions of their own ability to accomplish an academic task, which consequently leads to academic success. Research has identified various factors that may have a great influence on the development of students' academic self-efficacy. Bandura [5] stated that personal, social, and contextual variables can serve as factors which enhance the development of self-efficacy. The current study examines the effects of parenting styles on the development of students' academic self-efficacy beliefs through a cross-sectional design. It has been argued that the effects of parenting styles vary across years by comparing these effects for two separate samples from a school and a university.

\subsection{Literature Review}

\subsubsection{Definition and Importance of Students' Academic Self-efficacy}

Self-efficacy is grounded on the basis of social cognitive theory which focuses on the interaction between individuals' behavior, personal factors (e.g., beliefs and thoughts) in addition to environmental conditions [5]. Most research derived the definition of academic self-efficacy from Bandura's (pp. 2-3, [5]) 
general definition of self-efficacy, which is "beliefs in one's capabilities to organize and execute the courses of action required to produce given attainments".

Specifically, Bandura [5] defines academic self-efficacy beliefs as the individuals' beliefs that they can perform well academically to reach a particular goal. Other researchers [6-11] relate academic self-efficacy to self-confidence. They define academic self-efficacy as the amount of confidence that students may experience when completing academic tasks. This means that a student's self-efficacy is the academic confidence experienced due to completing academic tasks. Measured from an intrapersonal perspective, self-efficacy is seen related to a student's confidence in his/her ability to succeed academically $[12,13]$.

Fan and Williams [14] point out that academic achievement could be predicted by self-efficacy, since it affects the amount of students' effort and persistence. This is due to the fact that students who show high levels of self-efficacy are more likely to set forward the effort needed to overcome academic difficulties. Research further explains that a student who expresses greater levels of self-efficacy and believes in his/her ability to learn and succeed in an academic task can do academically better compared with students who self-doubt their ability to learn $[15,16]$.

Research has investigated the importance of self-efficacy for academic achievement. People with high self-efficacy can overcome obstacles and are more likely to pursue their own achievement goals [3,17-20]. Furthermore, a considerable amount of literature highlighted the influences of academic self-efficacy on academic motivation, learning, and academic achievement [21,22]. Fan and Williams [14] stress the importance and influence of self-efficacy on learning, as it influences students' choice of activities and their engagement in behaviors which are necessary to achieve certain goals. It also influences students' academic interest and motivation [23], in addition to their development of cognitive competencies and successfully completed achievement. Moreover, Bong and Skaalvik [7] believe that students' self-efficacy provides explanations and predictions of one's thoughts, emotions, and actions.

The important role of students' academic self-efficacy beliefs is also reported for university students. Al-Harthy and Aldhafri [24] found a positive correlation between university students' academic efficacy beliefs and their task values. Graci, Brown, Kelley and Zagumny [25] report that self-efficacy functions as a good predictor of any obstacle, failure or problem that can affect college students' academic achievement. In their research, they found that students' academic self-efficacy was significantly correlated with students' commitment to their majors. Korgan et al., [12] point out that self-efficacy is an important factor in undergraduate students' lives as it helps achieving academic tasks and can be a predictor of college grade point average (GPA).

It can be concluded that academic self-efficacy provides significant information for parents, scholars, policy makers and teachers to better understand and be more aware about the factors that affect students' academic achievement [12]. Little research, if any, tried to evaluate this importance across school and university years within one study. The current study compares the development of these beliefs across different schooling stages.

\subsubsection{The Developmental Changes in the Academic Self-Efficacy Beliefs}

According to Bandura [5], four major sources contribute to forming self-efficacy beliefs. The first source is enactive mastery experience which is considered the most reliable source of information. It is related to one's prior successes and failure. While successful experiences are said to strengthen self-efficacy, continuous failure weakens it. Therefore, temporary failure may be resisted by previous successes. Self-efficacy beliefs are also influenced by vicarious experience, which reflects other people's performance on the task. This has led us to conclude that one's self-efficacy beliefs are formed effectively through modelling. The third source is verbal persuasion which means that one's judgment of self-efficacy can be affected by persuasive communication and evaluative feedback from others. The last source of self-efficacy development is physiological reactions. This source includes physiological symptoms that influence people efficacy appraisal such as sweating, heartbeats, fatigue, 
aches, pain, and mood changes. Self-efficacy adjustment can be reached through recognition of these symptoms and their effects on cognitive processes.

Some or all of these sources are also considered the main factors that influence students' self-efficacy beliefs [26,27]. The development of academic self-efficacy is regarded as a complex process [12]. Research suggests that students' self-efficacy changes when they experience different situations [26]. Schunk and Meece [15] write about the developmental changes (cognitive, physical, and social changes) that adolescents undergo, and how these changes influence the way adolescents view their self-perceptions and capabilities. They point out that the more skillful adolescents are at coordinating conflicting information and expectations, the more stable and integrated they become in forming views of their capabilities, values, and attributes.

At a college level, Phan [28] found that positive and negative academic experiences do make a change in the development of university students' academic self-efficacy. Students' negative mastery experiences in elementary and secondary school lower their later self-efficacy because continuous negative experiences decrease levels of self-efficacy [23].

Thus, the academic self-efficacy beliefs of school and university students are influenced by a set of factors that cause a change in students' self-perceptions. These developmental changes may differ according to their previous academic experience, age level, and social context.

Recently, the effect of academic motivations on the development of college students' self-efficacy was examined by Kyndt et al. [29]. The researchers explored the development of Belgium students' motivation across the transition from school to university level over a period of about two years. The findings are explained based on two main theories which are self-determination theory and social cognitive theory, and it has been found that the development of self-efficacy is predicted by the development of self-determined motivation.

Furthermore, one of the important factors that influence students' academic self-efficacy beliefs is their perception of parenting styles during their life. The effects of parenting styles can be understood as part of students' mastery experiences, vicarious experiences, and social persuasion. According to Rahimpour et al. [30], parenting styles significantly affect all stages of people's life from preschool until college. Fan and Williams [14] point out that parents affect the development of self-efficacy by providing some observational models that can guide adolescents' changes of their self-perceptions. Moreover, the researchers confirm that parents' encouragement of adolescents' capability results in low levels of self-doubt and a high ability of adolescents to overcome difficulties. Parenting style is mainly a contextual variable used to promote academic success. However, academic self-efficacy may serve as an external variable that mediates the effects of parenting styles on adolescents' academic performance [31]. Next, we define parenting styles and show their importance in relation to children's outcomes, especially connections with academic self-efficacy beliefs.

\subsubsection{The Definition and Importance of Parenting Styles}

Rahimpour et al. (p. 5, [30]) define parenting styles as "a psychological construct that represents parents' strategies used with their children". Researchers have proposed various parenting styles. Among the most common styles are those based on Baumrind's dimensions [32]: Demandingness and responsiveness. These styles are the authoritative parenting style, authoritarian parenting style, and the permissive parenting style.

Rivers et al. [31] define authoritative parents as 'parents who are demanding and responsive to their children at the same time, in addition to having a set of clear rules and expectations about their children's behavior and performance'. Children with authoritative parents are more likely to develop effective cognitive skills [33], are more confident on their skills, and experience high levels of psychological health and wellbeing [34]. Authoritarian parents are parents who are more demanding and less responsive. Adolescents in these families are considered more dependent, passive, and conforming despite their success in academic settings [31]. The third style is permissive parents, defined as parents who are less demanding but are highly responsive to adolescents. Adolescents 
of such parents are likely to be immature, irresponsible, and less involved in school settings [31]. Permissive parents care more about their children's needs but do not expect or control their children's behavior [30].

Each of these styles has its function and influence when examined in relation to children's psychological outcomes and characteristics. The authoritative parenting style was found to connect to positive children's outcomes including high academic performance [35-38], academic identity [39], intrinsic motivation [31], self-resilience [40,41], mental health and wellbeing [42-45]. In contrast, negative (e.g., permissive) and non-supportive (e.g., authoritarian) parenting styles are negatively related to children outcomes [46]. They are connected to children's violence [47] shyness, peer exclusion [48] internalizing and externalizing problems [49], anxiety, interpersonal problems, depression, self-esteem problems, family problems [50], and low levels of well-being [51]. Nevertheless, research examining the authoritarian style pointed to some positive influences in some cultures [52,53]. The effects of the authoritarian style might be positive or negative due to the differences in cultural contexts [54-57].

The next section elaborates on the effects of parenting styles on children's outcomes by reporting the findings of the studies that examined the connections between parenting styles and students' academic self-efficacy beliefs.

\subsubsection{The Relationship between Parenting Styles and Students' Academic Self-efficacy}

Few studies have investigated the relationship between parenting styles and students' self-efficacy beliefs. We first review available research that focused on school students and later on the college student context.

Juang and Silbereisen [58] investigated the relationship between German adolescent students' parenting practices, academic capability beliefs, and school grades. The results demonstrated that parents who showed more warmth and more involvement in their adolescents' academic concerns positively affect their children's academic capability beliefs and achievement. A longitudinal study investigated the effect of parental involvement on students' self-efficacy in math and English on grade 10 students. It was found that parents' positive involvement and advice were strong predictors of students' high academic self-efficacy in English [14]. Frank, Plunkett and Otten, [59] investigated parental support, parental knowledge, and parental psychological control perceptions of 158 Iranian American adolescents and their direct relationship with general self-efficacy, in addition to the indirect effects through positive esteem and self-deprecation. The statistical analysis provided evidence that parents' knowledge and psychological control have a direct relationship with general self-efficacy. Moreover, parenting variables, excluding fathers' knowledge, were also related to general self-efficacy, but indirectly through positive esteem or self-deprecation.

Griffith [60] studied the influence of parental engagement of immigrant parents from different origins on their children's academic experiences. Data analysis revealed that parental engagement positively influenced immigrant children's academic self-efficacy due to parents' educational backgrounds and beliefs. Furthermore, Rivers, Mullis, Fortner and Mullis [31] examined the connection between 148 high school students' perceptions of parenting styles and a group of motivational variables including academic self-efficacy beliefs. The results showed that academic self-efficacy belief was correlated positively with the authoritativeness and negatively with authoritarianism.

NaghibZadeh, Reza Fallahchai, and Sadeghi Fard, [61] examined the relationship between parenting styles and high-school female students' academic self-efficacy. The findings showed that the authoritative parenting styles significantly and positively predicted female students' academic self-efficacy. In contrast, the authoritarian and permissive styles showed significant negative relationships with students' academic self-efficacy. Seifi [62] examined the relationship between parenting styles and high school students' academic self-efficacy. The results revealed that parenting styles have a significant relationship with self-efficacy, and therefore, can strongly affect students' academic self-efficacy. It was noticed that the authoritative parenting style had a stronger effect on 
self-efficacy than the authoritarian parenting style. A recent study [63] examined the effects of parenting styles in a group of children's outcomes including self-efficacy beliefs, motivation, and academic achievement. The participants of the study were 422 Indonesian high school students. The results of the path analyses showed a direct effect of parenting styles on self-efficacy, which acted as a mediator in the relationship between parenting styles and science academic achievement.

As for college students, fewer studies were identified. For example, using an American sample, Korgan et al., [12] looked into the intrapersonal and environmental factors that affect first-year students' development of academic self-efficacy. The authors identified three main factors: family/home environment, peer environment, and academic environment. A Pakistani study analyzed the relationship between parenting styles and university students' academic performance, with self-efficacy as a mediating variable. It was noticed that only the relationship between the authoritative parenting style and students' academic performance was mediated by self-efficacy [64].

Similarly, in a study by Gonzalez [65], the researcher reports that the authoritative parenting style was not a significant indicator of university students' academic self-efficacy. Among the three parenting styles, it has been found that the authoritarian style had the greatest negative relationship with students' academic self-efficacy. Qamar, Parveen, and Yousuf [66] examined the relationship between perceived parenting styles and university students' academic self-efficacy. The results demonstrated a positive but weak statistically significant relationship between the authoritative style and university students' academic self-efficacy. In addition, no statistical significance was found regarding the relationship between students' academic self-efficacy and mothers' authoritative style, parents' authoritarian style, and permissive style. Recently, Macmull and Ashkenazi [67] examined a sample of 204 adults ( $85 \%$ were bachelor's holders) using measures of parenting styles and math efficacy beliefs and anxiety. The researchers found statistically significant positive relationships between the authoritative parenting style and students' self-efficacy beliefs. No statistically significant connections were found between efficacy beliefs and either authoritarian or permissive parenting styles.

\subsubsection{The Context of the Current Study}

It can be concluded that self-efficacy is an essential factor that is related to psychological development and contributes to students' further success [64]. The more positive experiences students receive from environmental and intrapersonal sources, the higher the level of academic self-efficacy they possess, and the more academic success they achieve at school or a higher education level.

Early research confirmed the relationship between parenting styles and students' academic self-efficacy but there were some variations in these relations across different parenting styles. In addition, many reviewed studies did not cover all three dimensions of parenting styles proposed by Baumrind's framework [32]. It is not clear yet how these three parenting styles function when used as predictors of students' academic self-efficacy beliefs especially when measured for each parent separately from the other parent. The need is further justified by examining this connection in a non-western context. It is expected that in collective cultures (such as Oman) the effects of parenting styles on children's outcomes persevere across age because of the role that family plays in the children's lives.

In addition, previous research did not examine how the relationships between parenting styles and students' academic self-efficacy beliefs may vary in school years compared to university years. Because of the varying environmental components at school and university, we hypothesize that the relationships between parenting styles and academic self-efficacy beliefs will be stronger during school years than during university years (Ecological framework [68]).

Therefore, the current study aimed to examine the relationships between Omani students' perceptions of parenting styles and their sense of academic self-efficacy beliefs. Particularly, we were interested in looking at these relationships using different sets of school and university samples. We also explored the levels of each of the parenting styles separately for mothers and fathers. In addition, the 
study identified the students' levels of academic self-efficacy beliefs, while examining possible gender differences in these variables.

\section{Materials and Methods}

\subsection{Sample}

Two sets of the sample were targeted in the current study with a total of 2550 school and university students responding to the study questionnaires. The participants come from different regions and districts in the Sultanate of Oman. The school student sample consisted of 1431 (51.6\% were females) from grades 7, 8, 9, and 10 from different parts of the country. Ages ranged from 10 to 17 years $(\mathrm{M}=13.87, \mathrm{SD}=1.16)$. The majority of the samples lived with both parents $(88.8 \%)$. The university student sample included 1119 students (61.3\% were females) from Sultan Qaboos University (SQU), a public university that serves students from different parts of the country. Most of the sample was from families with two parents (87.6\%). Enrollment in the university is free, and admission of students is on competitive basis, using their scores for the national grade 12 exams. All participants reported that they were either in their third or fourth year. Research assistants administered the questionnaires in the schools and at SQU. All returned questionnaires were usable with some missing data. Data were entered into an SPSS file, and no data replacement was used for the missing data. The researchers did not find any pattern that might represent a validity threat, especially considering the large data set used in the current study.

\subsection{Procedure}

Data collection of the current data took place in public schools and at Sultan Qaboos University in Oman. The researchers hired research assistants to help in data collection from the schools. Prior to data collection, permission was obtained from the ministry of education, each school district, and each participating school administration. School students responded to the questionnaires during their regular class time. The researchers or their assistant administrated the questionnaire with the help of the class teacher. The university data were collected after permission from the university administration and in coordination with class instructors.

The students in both samples were assured confidentiality and that their responses did not relate to school grades. The students were invited to participate on a voluntary base. All students who were present during data collection chose to participate in the study.

\subsection{Measures}

The researchers used two questionnaires. The first questionnaire is the Academic Self-Efficacy Scale (ASES) to examine students' perceptions of their academic efficacy beliefs. The second questionnaire is the Parental Authority Questionnaire (PAQ [69]) to measure the students' perceptions of their parenting styles. Descriptions of the two measures follow.

\subsubsection{The ASES}

The Academic Self-Efficacy Scale (ASES) includes six items that are worded in a positive direction. This scale is designed to survey adolescents' perceptions of the related schoolwork academic self-efficacy. It is designed on a 5-point Likert scale (ranges from $5=$ strongly agree, to $1=$ strongly disagree). Alkharusi [70] used a sample that includes Omani students from grade 7 to grade 12, which revealed a unifactor solution that provided an explanation for $54.25 \%$ of the total variance. Cronbach's alpha $(\alpha=0.83)$ was also reported by Aldhafri [34]. The current school sample obtained a similar unifactor solution to Alkharusi [70] (53.54\% of variance and an eigenvalue of 3.21), and the internal consistency coefficient was 0.82 . Similar results were obtained for the current university sample. The one-factor solution accounted for $65.89 \%$ of the variance with an eigenvalue of 3.95. An alpha coefficient of 0.90 was obtained. The following statements are adequate examples: "Even if the school work is hard, I can 
learn it" and "I am sure about my ability to do the assignments for my school/university subjects" as well.

\subsubsection{The PAQ}

The Parental Authority Questionnaire (PAQ [69]) examines three parenting styles; authoritarian, authoritative, and permissive parenting styles. In the current study, we used the short version of the PAQ that includes 20 items. Alkharusi and colleagues [71] used a sample of Omani students to explore the validity and reliability of the short questionnaire, which yielded adequate evidence. Previous studies [34] have recommended separating the examination of the mother's parenting style from the father's parenting style. Thus, the participants evaluated their mothers' styles by responding to 20 items and then they evaluated their fathers' styles using the same 20 items. All items were on a 5-point Likert scale, ranging from $5=$ strongly agree, to $1=$ strongly disagree. Out of the 20 items, seven items measured the authoritative style (example: Once the family policy had been established, my father/mother discussed the reasoning behind the policy with the children). Another seven items examined the authoritarian style (example: Whenever my father/mother told me to do something as I was growing up, he/she expected me to do it immediately without asking any questions.). The remaining six items focused on the permissive style (example: As I was growing up, my father/mother seldom gave me expectations and guidelines for my behavior). Using the current school sample data to examine the construct validity of the father's parenting style scale, the researchers used an exploratory factor analysis (with promax rotation and maximum likelihood extraction) and the results confirmed the theoretical structure of the scale. The three-factor solution explained $25.91 \%$ of the variance. The 20 items were loaded according to their dimensions, with loading values of 0.28 or above. The three father parenting styles had good reliability coefficients $(\alpha=0.62,0.74, \& 0.56)$, respectively. The results obtained for the mother's parenting styles scale were similar to the father's with some cross loading of a few items. The three-factor solution explained $23.33 \%$ of the variance and the loading values exceeded 0.25 . The reliability coefficients that were obtained for the three parenting styles, respectively, were $0.57,0.73$, and 0.52 .

Similar analyses were run using the university student sample. The exploratory factor analysis (using promax rotation and maximum likelihood extraction) supported a three-factor solution. This solution explained $36.26 \%$ of the variance on the construct of the father's parenting style, with items loading 0.33 or above in their theoretical dimensions. Alpha coefficients for the authoritarian, authoritative, and permissive parenting styles were higher than the values found for the school student data (father's styles: $0.76,0.83$, and 0.63 , respectively). Similarly, the factorial examination of the mother's parenting style indicated a similar structure of the three-factor model (37.64\% of the variance was explained) with loadings of 0.35 or above. The reliability Alpha coefficients for the three styles were adequate for the mother's styles: $0.75,0.81$, and 0.68 , respectively).

\subsection{Design}

The study adopted a descriptive comparative research design. The main goal of the study was to describe the relationship between students' perceptions of parenting styles and their academic self-efficacy beliefs. In addition, the analysis of the study included a comparison between the findings related to school students to those related to university students.

\subsection{Statistical Methods}

The researchers utilized a group of statistical methods. Descriptive analyses including means, standard deviations, and one-sample $t$-tests were used to examine the levels of the study variables. Pearson correlation coefficients described the bivariate relationships between each parenting style and students' academic self-efficacy beliefs. Two regression models (one for each sample) were used to examine the predictive role of parenting styles in predicting students' academic self-efficacy beliefs. 
Prior to the use of regression models, the researchers examined the expectations of a standard multiple regression. First, the sample size should be adequate to enable the researchers to generalize their results. According to the formula given by Tabachnick and Fidell (p. 123, [72]), the minimum sample size needed was $\left(5+8^{*} \mathrm{~m}\right)$ (where $\mathrm{m}$ represents the number of independent variables). For the current study, six independent variables were used (three father's styles and three mother's styles); therefore, a total of 98 cases should be used at minimum. Since the current school sample size consisted of 1431 cases and the university sample size included 1119 cases, generalizability was possible.

Second, multicollinearity was tested using part and partial correlations between the independent variables. Correlations between variables should not exceed $r=0.80$ in order to avoid multicollinearity [73]. Other indicators used to check for multicollinearity are Tolerance (not less than 0.1) and VIF (not more than 10). For both samples, the data showed that all correlations between independent variables were less than 0.80 . Data analysis of the school student sample also showed that Tolerance and VIF were in the accepted range for all independent variables (ranging from 0.40-0.50 for Tolerance, and from 1.97 to 2.46 for VIF). Similarly, in the university student sample, the obtained values were in the accepted range (ranging from $0.40-0.63$ for Tolerance, and from 1.56 to 2.46 for VIF).

Third, data were checked for outliers using the Mahalanobis distance. The observed Mahal.distance should be less than the critical $\mathrm{X} 2$ value at the degree of freedom equal to the number of independent variables (six variables in the current study) and $p=0.001$. For the current study, the observed Mahal.distance was 0.008 (for the school data) and 0.118 (for the university data). Both values are less than the critical X2 (22.46), which suggests that the two data sets are clear of outliers.

Fourth, normality, linearity, and homoscedasticity were all checked through residual scatterplots "residuals are the difference between the obtained and the predicted dependent variable score" (p. 151, [73]). For both sets of data, plots (not shown here) were scattered in parallel on both sides of the axis, which suggests the assumptions of normality, linearity, and homoscedasticity were met.

\section{Results}

The researchers examined descriptive statistics for the main variables of the student sample (Table 1) and for the university sample (Table 2). Reliability coefficients obtained from the current two samples are displayed in Tables 1 and 2.

Table 1. Means, Standard Deviations, and the One-Sample $t$-test for the School Sample Variables $(n=1431)$.

\begin{tabular}{lcccccc}
\hline Variable & Min. & Max. & $\boldsymbol{M}$ & $\boldsymbol{S D}$ & $\boldsymbol{t}$ & $\boldsymbol{\alpha}$ \\
\hline Academic Self-Efficacy & 1 & 5 & 3.60 & 0.85 & 26.65 & 0.82 \\
Authoritarian Mother & 1 & 5 & 3.32 & 0.68 & 17.84 & 0.57 \\
Authoritative Mother & 1 & 5 & 3.51 & 0.77 & 24.51 & 0.73 \\
Permissive Mother & 1 & 5 & 2.75 & 0.72 & -12.76 & 0.52 \\
Authoritarian Father & 1 & 5 & 3.42 & 0.72 & 21.39 & 0.62 \\
Authoritative Father & 1 & 5 & 3.53 & 0.79 & 24.49 & 0.74 \\
Permissive Father & 1 & 5 & 2.78 & 0.75 & -10.48 & 0.56 \\
\hline
\end{tabular}

Note. variation in the $n$ value across the investigated variables is because of missing data. Missing data replacement was deemed not necessary with the small number of missing data and the high amount of data available for the main data analyses. All means were higher than the theoretical mean $(M=3)$ at $<0.001$. 
Table 2. Means, Standard Deviations, and the One-Sample $t$-test for the University Sample Variables $(n=1119)$.

\begin{tabular}{lcccccc}
\hline Variables & Min. & Max. & $\boldsymbol{M}$ & SD & $\boldsymbol{t}$ & $\boldsymbol{\alpha}$ \\
\hline Academic Self-Efficacy & 1 & 5 & 4.16 & 0.60 & 63.99 & 0.90 \\
Authoritarian Mother & 1 & 5 & 3.41 & 0.74 & 18.62 & 0.75 \\
Authoritative Mother & 1 & 5 & 3.89 & 0.66 & 44.82 & 0.81 \\
Permissive Mother & 1 & 5 & 2.94 & 0.76 & -2.55 & 0.68 \\
Authoritarian Father & 1 & 5 & 3.42 & 0.76 & 18.56 & 0.76 \\
Authoritative Father & 1 & 5 & 3.73 & 0.74 & 32.99 & 0.83 \\
Permissive Father & 1 & 5 & 2.92 & 0.72 & -3.27 & 0.63 \\
\hline
\end{tabular}

Note. All means were higher than the theoretical mean $(M=3)$ at $<0.001$.

Using one-sample $t$-tests, the results of the student sample (displayed in Table 1) show that the participants have high levels of academic self-efficacy beliefs and they perceived their parents (both mothers and fathers) as more authoritative and authoritarian and less as permissive. A similar pattern was found for the university sample as displayed in Table 2 . The university sample, however, showed higher means in all the variables under investigation than the means found for the school student sample.

Gender differences in students' perceptions of parenting styles and their academic self-efficacy beliefs were tested using independent sample $t$-tests. Table 3 represents the results from the school sample.

Table 3. Gender Differences in Parenting Styles and Academic Self-Efficacy Beliefs for School Students.

\begin{tabular}{|c|c|c|c|c|c|c|c|}
\hline Variables & Gender & Number & $M$ & $S D$ & $t$ & $d f$ & $P$ \\
\hline \multirow{2}{*}{ Academic Self-Efficacy } & Male & 688 & 3.45 & 0.84 & \multirow[t]{2}{*}{6.43} & \multirow[t]{2}{*}{1421} & \multirow[t]{2}{*}{0.000} \\
\hline & Female & 735 & 3.74 & 0.83 & & & \\
\hline \multirow{2}{*}{ Authoritarian Mother } & Male & 684 & 3.27 & 0.71 & \multirow[t]{2}{*}{2.82} & \multirow[t]{2}{*}{1395} & \multirow[t]{2}{*}{0.005} \\
\hline & Female & 713 & 3.37 & 0.65 & & & \\
\hline \multirow{2}{*}{ Authoritative Mother } & Male & 684 & 3.40 & 0.77 & \multirow[t]{2}{*}{5.25} & \multirow[t]{2}{*}{1396} & \multirow[t]{2}{*}{0.000} \\
\hline & Female & 714 & 3.61 & 0.76 & & & \\
\hline \multirow{2}{*}{ Permissive Mother } & Male & 675 & 2.74 & 0.71 & \multirow[t]{2}{*}{0.37} & \multirow[t]{2}{*}{1384} & \multirow[t]{2}{*}{0.709} \\
\hline & Female & 711 & 2.75 & 0.73 & & & \\
\hline \multirow{2}{*}{ Authoritarian Father } & Male & 654 & 3.42 & 0.73 & \multirow[t]{2}{*}{0.12} & \multirow[t]{2}{*}{1326} & \multirow[t]{2}{*}{0.900} \\
\hline & Female & 674 & 3.42 & 0.70 & & & \\
\hline \multirow{2}{*}{ Authoritative Father } & Male & 652 & 3.46 & 0.79 & \multirow{2}{*}{3.30} & \multirow{2}{*}{1325} & \multirow{2}{*}{0.001} \\
\hline & Female & 675 & 3.60 & 0.78 & & & \\
\hline \multirow{2}{*}{ Permissive Father } & Male & 634 & 2.80 & 0.78 & \multirow{2}{*}{1.15} & \multirow{2}{*}{1294} & \multirow{2}{*}{0.248} \\
\hline & Female & 662 & 2.75 & 0.72 & & & \\
\hline
\end{tabular}

As can be seen in Table 3, there are some statistically significant differences in academic self-efficacy beliefs and in some parenting styles (authoritarian mother, authoritative mother, and authoritative father) attributed to gender favoring females. Similarly, the researchers explored possible gender differences for the university sample in academic self-efficacy beliefs and parenting styles as displayed in Table 4. The results show statistically significant gender differences in academic self-efficacy and in all parenting styles except the authoritative father. 
Table 4. Gender Differences in Parenting Styles and Academic Self-Efficacy Beliefs for University Students.

\begin{tabular}{|c|c|c|c|c|c|c|c|}
\hline Variables & Gender & Number & $M$ & $S D$ & $t$ & $d f$ & $P$ \\
\hline \multirow{2}{*}{ Academic Self-Efficacy } & Male & 424 & 4.09 & 0.65 & \multirow[t]{2}{*}{2.87} & \multirow[t]{2}{*}{1108} & \multirow[t]{2}{*}{0.004} \\
\hline & Female & 686 & 4.20 & 0.57 & & & \\
\hline \multirow{2}{*}{ Authoritarian Mother } & Male & 424 & 3.49 & 0.69 & \multirow{2}{*}{3.02} & \multirow{2}{*}{1108} & \multirow{2}{*}{0.003} \\
\hline & Female & 686 & 3.35 & 0.76 & & & \\
\hline \multirow{2}{*}{ Authoritative Mother } & Male & 424 & 3.84 & 0.66 & \multirow[t]{2}{*}{2.17} & \multirow[t]{2}{*}{1108} & \multirow[t]{2}{*}{0.030} \\
\hline & Female & 686 & 3.93 & 0.67 & & & \\
\hline \multirow{2}{*}{ Permissive Mother } & Male & 424 & 3.09 & 0.72 & \multirow[t]{2}{*}{5.38} & \multirow[t]{2}{*}{1108} & \multirow[t]{2}{*}{0.000} \\
\hline & Female & 686 & 2.84 & 0.77 & & & \\
\hline \multirow{2}{*}{ Authoritarian Father } & Male & 424 & 3.49 & 0.76 & \multirow[t]{2}{*}{2.58} & \multirow[t]{2}{*}{1108} & \multirow[t]{2}{*}{0.010} \\
\hline & Female & 686 & 3.37 & 0.76 & & & \\
\hline \multirow{2}{*}{ Authoritative Father } & Male & 424 & 3.70 & 0.75 & \multirow{2}{*}{1.16} & \multirow{2}{*}{1108} & \multirow{2}{*}{0.244} \\
\hline & Female & 686 & 3.75 & 0.74 & & & \\
\hline \multirow{2}{*}{ Permissive Father } & Male & 424 & 3.04 & 0.73 & \multirow{2}{*}{4.46} & \multirow{2}{*}{1108} & \multirow{2}{*}{0.000} \\
\hline & Female & 686 & 2.85 & 0.71 & & & \\
\hline
\end{tabular}

Bivariate Pearson correlation coefficients were also examined among the study variables for both samples as presented in Table 5. For the school student sample (results displayed under the diagonal), authoritative (for mother and father) and authoritarian (for mother and father) parenting styles show statistically significant positive correlations with academic self-efficacy (ranging from 0.28 to 0.41 ). The permissive parenting styles did not reach significance with academic self-efficacy. The correlation coefficients among the six parenting styles were all statistically significant except between the permissive father and authoritative mother. Other significant correlations ranged from 0.05 to 0.74 (all except one were significant at $p \leq 0.001$ ).

Table 5. Correlation coefficients between students' academic self-efficacy and parenting styles.

\begin{tabular}{lccccccc}
\hline Variables & ASE & ANM & AVM & PRM & ANF & AVF & PRF \\
\hline ASE & - & 0.03 & $0.30^{* *}$ & 0.00 & 0.02 & $0.24^{* *}$ & -0.01 \\
ANM & $0.28^{* *}$ & - & $0.11^{* *}$ & $0.30^{* *}$ & $0.65^{* *}$ & $0.12^{* *}$ & $0.30^{* *}$ \\
AVM & $0.41^{* *}$ & $0.47^{* *}$ & - & $0.07^{* *}$ & $0.15^{* *}$ & $0.57^{* *}$ & 0.30 \\
PRM & $0.00^{* *}$ & $0.33^{* *}$ & $0.11^{* *}$ & - & $0.20^{* *}$ & $0.09^{* *}$ & $0.75^{* *}$ \\
ANF & $0.28^{* *}$ & $0.68^{* *}$ & $0.40^{* *}$ & $0.25^{* *}$ & - & $0.10^{* *}$ & $0.24^{* *}$ \\
AVF & $0.39^{* *}$ & $0.39^{* *}$ & $0.69^{* *}$ & 0.05 & $0.40^{* *}$ & - & $0.16^{* *}$ \\
PRF & -0.02 & $0.27^{* *}$ & $0.02^{* *}$ & $0.74^{* *}$ & $0.26^{* *}$ & $0.09^{* *}$ & - \\
\hline
\end{tabular}

Note. ASE: academic self-efficacy; ANM: authoritarian mother; AVM: authoritative mother; PRM: permissive mother; ANF: authoritarian father; AVF: authoritative father; PRF: permissive father. ${ }^{* *}$ Significant at $\leq 0.01$. Correlations above the diagonal are for the university sample and the correlations beneath the diagonal are for the school sample.

The correlation coefficients found for the university sample indicated significant correlation coefficients between academic self-efficacy and an authoritative mother and father. The other four parenting styles did not reach significance in their relationship with academic self-efficacy beliefs. The results also showed that all correlation coefficients among the six parenting styles were statistically significant (ranging from 0.09 to 0.65 ; all were significant at $p \leq 0.002$ ) except between the authoritative father and permissive mother. The correlation coefficients of the university sample are shown above the diagonal in Table 5.

To examine the predictive value of parenting styles in predicting students' academic self-efficacy beliefs, two regression models were developed. The first model used school students' data and the second model examined the university student data. All parenting styles were used in the prediction model to control for possible interactions among the predicting variables, even though some of them did not reach significance in their bivariate correlations with academic self-efficacy beliefs. 
To predict school students' academic self-efficacy beliefs, the researchers entered the six parenting styles into the regression model using the default function of linear regression. As presented in Table 6, the model containing the six parenting styles explained $21 \%$ of the variance in the dependent variable (i.e., students' academic self-efficacy beliefs), and only three parenting styles were significant predictors. These included the authoritarian father $(\beta=0.10, p=0.003)$, authoritative father $(\beta=0.19, p<0.001)$, and authoritative mother $(\beta=0.21, p<0.001)$ styles.

Table 6. Results of the Multiple Regression Models to Predict Students' Academic Self-Efficacy Beliefs-School Sample.

\begin{tabular}{lcccccc}
\hline Model & $\boldsymbol{B}$ & $\boldsymbol{S . E}$ & $\boldsymbol{\beta}$ & $\boldsymbol{t}$ & sig & $\boldsymbol{R}^{\mathbf{2}}$ \\
\hline Constant & 1.72 & 0.14 & - & 12.34 & 0.000 & \\
Authoritarian Mother & 0.06 & 0.04 & 0.05 & 1.42 & 0.154 & \\
Authoritative Mother & 0.23 & 0.04 & 0.21 & 5.56 & 0.000 & 0.21 \\
Permissive Mother & -0.05 & 0.04 & -0.04 & -1.07 & 0.281 & \\
Authoritarian Father & 0.12 & 0.04 & 0.10 & 3.00 & 0.003 & \\
Authoritative Father & 0.20 & 0.04 & 0.19 & 5.06 & 0.000 & \\
Permissive Father & -0.06 & 0.04 & -0.06 & -1.55 & 0.119 & \\
\hline
\end{tabular}

Another regression model was developed for the university sample to understand the relationship between parenting styles and academic self-efficacy beliefs (Table 7). All six parenting styles were entered into the regression equation as predictor variables that are expected to influence students' academic self-efficacy beliefs. The results of the university student data show that the model with the six parenting styles accounted for only $10 \%$ of variance in students' academic self-efficacy beliefs. Among the six parenting styles, only the authoritative father $(\beta=0.10, p=0.003)$ and authoritative mother $(\beta=0.24, p<0.001)$ were significant predictors of self-efficacy beliefs.

Table 7. Results of the Multiple Regression Models to Predict Students' Academic Self-Efficacy Beliefs-University Sample.

\begin{tabular}{lcccccc}
\hline Model & $\boldsymbol{B}$ & $\boldsymbol{S} . \boldsymbol{E}$ & $\boldsymbol{\beta}$ & $\boldsymbol{t}$ & $\boldsymbol{s i g}$ & $\boldsymbol{R}^{\mathbf{2}}$ \\
\hline Constant & 3.08 & 0.13 & - & 22.55 & 0.000 & \\
Authoritarian Mother & 0.02 & 0.03 & 0.03 & 0.79 & 0.430 & \\
Authoritative Mother & 0.22 & 0.03 & 0.24 & 6.96 & 0.000 & 0.10 \\
Permissive Mother & 0.00 & 0.03 & 0.00 & 0.06 & 0.945 & \\
Authoritarian Father & -0.02 & 0.03 & -0.03 & -0.95 & 0.338 & \\
Authoritative Father & 0.08 & 0.02 & 0.10 & 2.97 & 0.003 & \\
Permissive Father & -0.03 & 0.03 & -0.04 & -1.01 & 0.313 & \\
\hline
\end{tabular}

\section{Discussion}

The current study aimed to investigate possible developmental differences due to the effects of parenting styles on students' academic self-efficacy beliefs using two samples of school and university students. Prior to examining the relationships among the study variables, the researchers also examined the levels of students' academic self-efficacy beliefs and the students' perceptions of parenting styles. Gender differences were also examined. To achieve the main goal of the study, two regression models were developed across two different samples that included school and university students.

\subsection{Levels of Efficacy Beliefs and Parenting Styles}

The results showed that both samples had high levels of academic self-efficacy beliefs. The results are consistent with early research that examined students' academic self-efficacy beliefs and found high levels of this motivational component among Omani students $[24,74,75]$. The means reported by university students, however, were higher than those reported by school students. This may indicate 
some possible developmental changes in the students' perceptions of their academic efficacy beliefs. University students may feel more control over their learning process and feel more efficacious to master different academic skills and strategies. College-level research shows that those students have high levels of achievement goals, self-efficacy, and grit [76]. This reflects the nature of higher education which promotes higher levels of self-regulated learning and expects higher levels of independence than those at school levels. This comparison between the two group means, however, is limited by the absence of direct statistical tests utilized in the current study.

The two samples also showed high levels of authoritative and authoritarian parenting styles and low levels of permissive parenting styles. The findings are in coherence with cumulative research done on Omani samples, especially for school students [34,52,77,78]. It seems that Omani parents tend to enforce regulations, guides, restrictions, and at the same time are willing to listen and have dialogues with their children when imposing their instructions. These two parenting styles are dominant in Middle Eastern and Eastern countries with less likelihood of having permissive parenting styles $[79,80]$. This kind of parenting (having high authoritative, authoritarian, and low permissive styles) is healthy for the development of children. Early parenting research shows that this combination of parenting styles is associated with positive psychological, academic, social, and behavioral children's outcomes [33,42,45].

The levels of these parenting styles, however, varied based on the students' gender. The statistical analyses of the school students' data showed that girls' perceptions of an authoritarian mother, authoritative mother and authoritative father were higher than those reported by boys. These findings are consistent with previous research [81-83]. Because of the family structure of the Omani families, females interact with their mothers more than boys do. Accordingly, they feel that the mothers' styles are a mix of high levels of demand and responsiveness. Their views about their fathers, however, reflect that fathers may not put high demands on their daughters compared to the mothers' demands on girls. This family relationship structure is true during school years as children spend their school years within the family context. These gender differences, however, differed for the university students. Girls had more positive views of their parents (higher authoritativeness) than boys who viewed their parents as more authoritarian. These differences may reflect boys' high desire for independence and autonomy during university years.

Gender differences were also observed in the students' academic self-efficacy beliefs. Across the two samples, the girls' levels of efficacy beliefs were higher than those of boys. The findings are consistent with previous research done in Oman [78] and in other countries [67]. Girls are motivated to work hard and achieve high grades in schools and tend to show high academic motivation to prove their high ability in academic domains, contradicting the normal stereotypes related to their achievement compared to their male counterparts. Girls are also motivated to outperform boys as a result of the family and teachers' stress on the value of academic success as a means of achieving high social and job status [67].

\subsection{Predicting Academic Self-Efficacy Beliefs}

The results of the regression models support the importance of parenting styles in predicting students' academic self-efficacy beliefs. The findings show that $21 \%$ of the variance in school students' self-efficacy beliefs and $10 \%$ of the variance in university students' efficacy beliefs are explained by the model of the three parenting styles (separately for fathers and mothers). This confirms different theoretical models (e.g., Bandura, motivational model and social ecological model) that emphasize the important role of families in the development of students' behavior, academic motivation, and values $[45,84]$. Moreover, the results stress the need to facilitate productive environmental factors that work in congruence with the teachers' efforts to foster high levels of academic motivation in students during their school and university years.

The regression findings, however, show that not all parenting styles have significant influences on the development of students' academic self-efficacy beliefs. Indeed, even though most of the parenting 
styles showed significant bivariate correlation coefficients in relation to students' self-efficacy beliefs, only authoritative parenting (both for mothers and fathers) contributed significantly to the variance explained in students' academic self-efficacy beliefs. This was true for both samples at school and university levels. The results showed that as parents adopt authoritative parenting styles, their children are more likely to develop high levels of academic efficacy beliefs. Authoritative styles are characterized by a mix of guidelines, supervisions, instructions, and effective communication strategies that ensure open and direct contact between parents and children within reciprocal respect, love, and collaborative life activities [33,57].

Two additional important findings from the current study should be also noted. The first is related to the positive significant effects of the father authoritarian style on school students' academic self-efficacy beliefs. Cross-cultural research uncovered inconsistent findings related to the effects of the authoritarian parenting style on the development of children. Some researchers, especially in Middle Eastern and Eastern countries, found positive impacts for the authoritarian parenting style on children's outcomes [80,85-87]. Most Western research, however, showed negative influences when parents adopt authoritarian styles in rearing their children [88-92]. The current study shows that at least during school years it might be good to have an authoritarian father style to ensure high levels of students' academic self-efficacy beliefs. This result is consistent with findings reported for Arab communities that are characterized by the important authoritarian role of men ensuring children's good behavior [80].

Another important noticeable finding from the current study is the observed difference between the amount of variance accounted for by the parenting styles between the school sample and the university sample. It seems that parents have higher impact on their children's academic self-efficacy beliefs during school years compared with university years. During adolescence, students' school work is subjected to parental influences, and parents may enhance or undermine their children's motivation through their parenting styles [76]. As children grow up and move to university, this influence decreases. During university years, children become distant from their parents and are more likely to live away from their home, and they become more independent in managing their college work. Consequently, their motivation (including self-efficacy beliefs) becomes more influenced by other related factors (e.g., personal, peers, etc.) and less by their home environment.

\subsection{Limitations and Future Directions}

Our conclusions and findings are limited by our research design and the statistical analyses utilized in the current study. First, the data are based on self-reporting that can be influenced by social desirability. Second, when comparing the relationships between parenting styles and self-efficacy beliefs, the current study did not implement direct statistical analyses to compare the results of the two samples of the study. Rather, we preferred to examine these relationships separately for each sample to simplify the statistical method as a means of focusing the analyses on the pure connections of parenting and efficacy per se.

Future research may extend the current comparison utilized in the current study to include other possible comparisons of factors affecting students' motivation and academic achievement starting from elementary school years and moving to university levels. Longitudinal studies can help understand possible developmental differences that we could not examine due to the limitation of the cross-sectional design.

Future research should consider more complex designs that use mediational models to account for possible personal mediational variables in the relationship between parenting styles and children's outcomes. It is argued that academic self-efficacy can be a result of the interaction between students' intrapersonal characteristics and environmental factors. It was found that resilience and emotional response are strong intrapersonal factors that influence the development of first-year college students' academic self-efficacy. Higher student resilience leads to lower internalization of negative environmental messages, which in turn results in increased levels of academic self-efficacy [12]. 
Other research has concluded that stress, gender, level of education, level of commitment to a current major, and students' judgement about their performance at college are regarded as factors that may predict and influence freshmen's academic self-efficacy [25].

\subsection{Implications and Conclusion}

Taking into account our findings of the connections between parenting styles and students' academic self-efficacy beliefs, training programs can be developed to help parents adopt positive parenting styles (e.g., authoritative styles) to promote the development of their children's efficacy beliefs, and hence their academic achievement. These programs can be designed using the principals of social cognitive theory and other related learning theories.

To conclude, our study contributes significantly to the available literature related to the influence of parents on children's outcomes. The inclusion of two samples from different schooling and developmental stages sheds light on the possible changes in the relationships between parenting styles and children's academic self-efficacy beliefs. It also confirms the importance of differentiating between maternal and paternal styles when examining parenting style effects on children's characteristics. Furthermore, our study supports possible cultural differences on the effects of authoritarian parenting styles on children's life and calls for the importance of acknowledging the cultural values of any population when examining parenting styles and other home-related factors.

Author Contributions: Conceptualization, S.S.A., Data curation, S.S.A.; Formal analysis, S.S.A.; Investigation, S.S.A.; Methodology, S.S.A.; Project administration, S.S.A.; Resources, S.S.A.; Software, S.S.A.; Supervision, S.S.A.; Validation, S.S.A., M.N.A., H.A.A., I.S.A.-H., H.S.A.-B. and A.S.A.; Writing-original draft, S.S.A.; Writing一review \& editing, S.S.A., M.N.A., H.A.A., I.S.A.-H., H.S.A.-B. and A.S.A. All authors have read and agreed to the published version of the manuscript.

Funding: This research was funded by Sultan Qaboos University.

Acknowledgments: We would like to thank the Research Council and the Motivation and Parenting Styles Research Group at Sultan Qaboos University for their research resource support.

Conflicts of Interest: The authors declare no conflict of interest.

\section{References}

1. Afari, E.; Ward, G.; Khine, M.S. Global self-esteem and self-efficacy correlates: Relation of academic achievement and self-esteem among Emirati students. Int. Educ. Stud. 2012, 5, 49-57. [CrossRef]

2. Pouratashi, M.; Zhub, C.; Mohammadi, H.; Rezvanfara, A.; Hosseinia, S. Effects of agricultural students' self-efficacy beliefs and test anxiety on their achievement motivation and academic performance. New Educ. Rev. 2013, 34, 85-98.

3. Manzano-Sanchez, H.; Outley, C.; Gonzalez, J.; Matarrita-Cascante, D. The influence of self-efficacy beliefs in the academic performance of Latina/o students in the United States: A systematic literature review. Hisp. J. Behav. Sci. 2018, 40, 176-209. [CrossRef]

4. Martin, A.J.; Malmberg, L.-E.; Kennett, R.; Mansour, M.; Papworth, B.; Pearson, J. What happens when students reflect on their self-efficacy during a test? Exploring test experience and test outcome in science. Learn. Individ. Differ. 2019, 73, 59-66. [CrossRef]

5. Bandura, A. Self-Efficacy: The Exercise of Control; W. H. Freeman: New York, NY, USA, 1997.

6. Bong, M.; Clark, R.E. Comparison between self-concept and self-efficacy in academic motivation research. Educ. Psychol. 1999, 34, 139-153. [CrossRef]

7. Bong, M.; Skaalvik, E. Academic self-concept and self-efficacy: How different are they really? Educ. Psychol. Rev. 2003, 15, 1. [CrossRef]

8. Pietsch, J.; Walker, R.; Chapman, E. The relationship among self-concept, self-efficacy, and performance in mathematics during secondary school. J. Educ. Psychol. 2003, 95, 589. [CrossRef]

9. Choi, N. Self-efficacy and self-concept as predictors of college students' academic performance. Psychol. Sch. 2005, 42, 197-205. [CrossRef]

10. Ferla, J.; Valcke, M.; Cai, Y. Academic self-efficacy and academic self-concept: Reconsidering structural relationships. Learn. Individ. Differ. 2009, 19, 499-505. [CrossRef] 
11. Usta, H.G. Examination of the relationship between TEOG score transition (from basic to secondary education), self-confidence, self-efficacy and motivation level. J. Educ. Pract. 2017, 8, 36-47.

12. Korgan, C.; Durdella, N.; Stevens, M. The development of academic self-efficacy among first-year college students in a comprehensive public university. High. Educ. Rev. 2013, 10,11-37.

13. Pampaka, M.; Swain, D.; Jones, S.; Williams, J.; Edwards, M.; Wo, L. Validating constructs of learners' academic self-efficacy for measuring learning gain. High. Educ. Pedagog. 2018, 3, 118-144. [CrossRef]

14. Fan, W.; Williams, C. The effects of parental involvement on students' academic self-efficacy, engagement and intrinsic motivation. Educ. Psychol. 2010, 30, 53-74. [CrossRef]

15. Schunk, D.; Meece, J. Self-efficacy development in adolescences. In Self-Efficacy Beliefs of Adolescents; Urdan, T., Pajares, F., Eds.; Information Age Publishing: Greenwich, CT, USA, 2005.

16. Abdul Gafoor, K.; Ashraf, M. Influence of school-image on academic self-efficacy belief. Innov. Res. Educ. 2017, 2, 51-58.

17. Diseth, A. Self-efficacy, goal orientations and learning strategies as mediators between preceding and subsequent academic achievement. Learn. Individ. Differ. 2011, 21, 191-195. [CrossRef]

18. Komarraju, M.; Nadler, D. Self-efficacy and academic achievement: Why do implicit beliefs, goals, and effort regulation matter? Learn. Individ. Differ. 2013, 25, 67-72. [CrossRef]

19. Huang, C. Achievement goals and self-efficacy: A meta-analysis. Educ. Res. Rev. 2016, 19, 119-137. [CrossRef]

20. Ansong, D.; Eisensmith, S.R.; Okumu, M.; Chowa, G.A. The importance of self-efficacy and educational aspirations for academic achievement in resource-limited countries: Evidence from Ghana. J. Adolesc. 2019, 70, 13-23. [CrossRef]

21. Guo, Y.; Klein, B.; Ro, Y. On the effects of student interest, self-efficacy, and perceptions of the instructor on flow, satisfaction, and learning outcomes. Stud. High. Educ. 2019. [CrossRef]

22. Schunk, D.; Pajares, F. The development of academic self-efficacy. In Development of Achievement Motivation; Wigfield, A., Eccles, J., Eds.; Academic Press: San Diego, CA, USA, 2002.

23. Van Dinther, M.; Dochy, F.; Segers, M. Factors affecting students' self-efficacy in higher education. Educ. Res. Rev. 2011, 6, 95-108. [CrossRef]

24. Al-Harthy, I.; Aldhafri, S. The Relationship among task-value, self-efficacy and academic achievement in Omani students at Sultan Qaboos University. Int. Rev. Soc. Sci. Humanit. 2014, 7, 15-22.

25. Graci, A.; Brown, C.; Kelley, J.; Zagumny, M. The role of academic self-efficacy in student success. Tntech, 1. Available online: https://publish.tntech.edu/index.php/PSRCI/article/view/39/1 (accessed on 1 January 2020).

26. Jenson, R.J.; Petri, A.N.; Day, A.D.; Truman, K.Z.; Duffy, K. Perceptions of self-efficacy among STEM students with disabilities. J. Postsecond. Educ. Disabil. 2011, 24, 269-283.

27. Septiyana, W.; Asih, E.; Dasari, D. The enhancement of mathematical problem-solving skill and self-efficacy achievement through thinking actively in a social context learning model. J. Phys. Conf. Ser. 2019, 1280, 1-8. [CrossRef]

28. Phan, H. Interrelations between self-efficacy and learning approaches: A developmental approach. Educ. Psychol. 2011, 31, 225-246. [CrossRef]

29. Kyndt, E.; Donche, V.; Coertjens, L.; Van Daal, T.; Gijbels, D.; Van Petegem, P. Does self-efficacy contribute to the development of students' motivation across the transition from secondary to higher education? Eur. J. Psychol. Educ. 2019, 34, 457-478. [CrossRef]

30. Rahimpour, P.; Direkvand-Moghadam, A.; Direkvand-Moghadam, A.; Hashemian, A. Relationship between the parenting styles and students' educational performance among Iranian girl high school students, a crosssectional study. J. Clin. Diagn. Res. 2015, 9, 5-7. [CrossRef]

31. Rivers, J.; Mullis, A.; Fortner, L.; Mullis, R. Relationships between parenting styles and the academic performance of adolescents. J. Fam. Soc. Work 2012, 15, 202-216. [CrossRef]

32. Baumrind, D. The influence of parenting style on adolescent competence and substance use. J. Early Adolesc. 1991, 11, 56-95. [CrossRef]

33. Kim, H.; Chung, R.G. Relationship of recalled parenting style to self-perception in Korea American college students. J. Genet. Psychol. 2003, 164, 481-492. [CrossRef]

34. Aldhafri, S. Self-efficacy and physical self-concept as mediators of parenting influence on adolescents' adjustment and wellbeing. J. Psychol. Afr. 2011, 21, 511-520. [CrossRef] 
35. Brown-Richards, C. Authoritative Parenting and the Relationship to Academic Achievement: Views of Urban African American Adolescents. Ph.D. Thesis, St. John Fisher College, Rochester, NY, USA, 2011. Available online: https://fisherpub.sjfc.edu/cgi/viewcontent.cgi?article=1067\&context=education_etd (accessed on 1 January 2020).

36. Checa, P.; Gutierrez, A.A. Parenting styles, academic achievement and the influence of culture. Psychol. Psychother. Res. Stud. 2018, 1. [CrossRef]

37. Masud, H.; Thurasamy, R.; Ahmad, M.S. Parenting styles and academic achievement of young adolescents: A systematic literature review. Qual. Quant. 2015, 49, 2411-2433. [CrossRef]

38. Nyarko, K. The influence of authoritative parenting style on adolescents' academic achievement. Am. J. Soc. Manag. Sci. 2011, 2, 278-282. [CrossRef]

39. Aldhafri, S.; Al-Harthy, I. Undergraduate Omani students' identity and perceptions of parenting styles. Rev. Eur. Stud. 2016, 8, 114-123. [CrossRef]

40. Kritzas, N.; Grobler, A.A. The relationship between perceived parenting styles and resilience during adolescence. J. Child Adolesc. Ment. Health 2005, 17. [CrossRef]

41. Zakeri, H.; Jowkar, B.; Razmjoee, M. Parenting styles and resilience. Procedia-Soc. Behav. Sci. 2010, 5, 1067-1070. [CrossRef]

42. Arab, A.; Sedrpoushan, N.; Javadzade, A. A social work study on relationship between parenting styles and career aspirations as well as psychological well-being. Manag. Sci. Lett. 2013, 3, 1937-1942. [CrossRef]

43. Khodabakhsh, M.R.; Kiani, F.; Ahmedbookani, S. Psychological well-being and parenting styles as predictors of mental health among students: Implication for health promotion. Int. J. Pediatrics 2014, 2, 39-46.

44. Lavasani, M.G.; Borhanzadeh, S.; Afzali, L.; Hejazi, E. The relationship between perceived parenting styles, social support with psychological well-being. Procedia-Soc. Behav. Sci. 2011, 15, 1852-1856. [CrossRef]

45. Xiong, R.; Li, S.; Xia, Y. A longitudinal study of authoritative parenting, juvenile delinquency and crime victimization among Chinese adolescents. Int. J. Environ. Res. Public Health 2020, 17, 1405. [CrossRef]

46. Kuppens, S.; Ceulemans, E. Parenting styles: A Closer look at a well-known concept. J. Child Fam. Stud. 2019, 28, 168-181. [CrossRef] [PubMed]

47. Spano, R.; Rivera, C.; Bolland, J.M. Does parenting shield youth from exposure to violence during adolescence? A 5-year longitudinal test in a high-poverty sample of minority youth. J. Interpers. Violence 2011, 26, 930-949. [CrossRef] [PubMed]

48. Miller, S.; Tserakhava, V.; Miller, C. My child is shy and has no friends: What does parenting have to do with it? J. Youth Adolesc. 2011, 40, 442-452. [CrossRef] [PubMed]

49. Esther, C.; Sales, A.; O'Gara, J. Maternal depression and acculturative stress impacts on Mexican-origin children through authoritarian parenting. J. Appl. Dev. Psychol. 2019, 63, 65-75. [CrossRef]

50. Klein, M.; Pierce, J. Parental care aids, but parental overprotection hinders college adjustment. J. Coll. Stud. Retent. 2009, 11, 167-181. [CrossRef]

51. Driscoll, A.; Russell, S.; Crockett, L. Parenting styles and youth well-being across immigrant generations. J. Fam. Issues 2008, 29, 185-209. [CrossRef]

52. Aldhafri, S. The Parenting Styles in the Omani Families: Your Children, How to Raise Them? Alnahdhah Press: Muscat, Oman, 2014.

53. Jaber, J.; Abduraheem, A. Alaalaqah bin azmat alnmo a'nfsei alegtmaei wasalib almoa'mlah alwaldiah lda ainat $\mathrm{mn}$ atalamith alqatarien [The relationship between social and psychological developmental crises and parenting styles for a sample of Qatari students]. J. Educ. Res. Cent. 1993, 2, 109-139.

54. Chan, K.; Chan, S. Emotional autonomy and perceived parenting styles: Relational analysis in the Hong Kong cultural context. Asia Pac. Educ. Rev. 2009, 10, 433-443. [CrossRef]

55. Chen, F.; Luster, T. Factors related to parenting practices in Taiwan. Early Child Dev. Care 2002, 172, 413-430. [CrossRef]

56. Cheung, C.; McBirde-Chang, C. Relations of perceived maternal parenting style, practices and learning motivation to academic components in Chinese children. Merrill-Palmer Q. 2008, 54,1-22. [CrossRef]

57. Sahithya, B.; Manohari, S.; Vijaya, R. Parenting styles and its impact on children-A cross cultural review with a focus on India. Ment. Health Relig. Cult. 2019, 22, 357-383. [CrossRef]

58. Juang, L.; Silbereisen, R. The relationship between adolescent academic capability beliefs, parenting and school grades. J. Adolesc. 2002, 25, 3-18. [CrossRef] [PubMed] 
59. Frank, G.; Plunkett, S.; Otten, M. Perceived Parenting, Self-Esteem, and General Self-Efficacy of Iranian American Adolescents. J. Child Fam. Stud. 2010, 19, 738-746. [CrossRef]

60. Griffith, C. Parental Engagement on Student Academic Self-Efficacy and Educational Attainment Expectation for Immigrant Youth. Master's Thesis, University of Louisville, Louisville, KY, USA, 2012.

61. NaghibZadeh, M.; Fallahchai, S.R.; Fard, M.S. Examine the relationship between parenting styles and parental perfectionism and self-efficacy among students school. J. Appl. Environ. Biol. Sci. 2014, 4, 98-101.

62. Seifi, M. The Effects of parenting styles on students' self-efficacy. Int. J. Humanit. Cult. Stud. 2016, 1, 2193-2200.

63. Dwisarini, N. Direct and indirect effects of parenting style, self-efficacy, and achievement motivation on science learning achievement of junior high school students. J. Pendidik. Sains 2020, 8, 32-40. [CrossRef]

64. Masud, H.; Ahmad, M.; Jan, F.; Jamil, A. Relationship between parenting styles and academic performance of adolescents: Mediating role of self-efficacy. Asia Pac. Educ. Rev. 2016, 17, 121-131. [CrossRef]

65. Gonzalez, A. The Effect of Parenting Styles on Academic Self-Efficacy, Resilience, and Help Seeking. Master's Thesis, Central Washington University, Ellensburg, WA, USA, 2017.

66. Qamar, A.; Parveen, Q.; Yousuf, M. Relationship between parenting styles and academic self-efficacy of students. Anthropologist 2017, 28, 123-129. [CrossRef]

67. Macmull, M.S.; Ashkenazi, S. Math Anxiety: The relationship between parenting style and math self-efficacy. Front. Psychol. 2019, 10, 1721. [CrossRef]

68. Paiva, J.C.; Morais, C.; Moreira, L. Activities with parents on the computer: An ecological framework. Educ. Technol. Soc. 2017, 20, 1-14.

69. Buri, J. Parental Authority Questionnaire. J. Personal. Assess. 1991, 57, 110-119. [CrossRef] [PubMed]

70. Alkharusi, H. Classroom assessment environment, self-efficacy, and mastery goal orientation: A causal model. INTI J. Spec. Issue Teach. Learn. 2009, 104-116. Available online: http://eprints.intimal.edu.my/id/eprint/409 (accessed on 13 July 2016).

71. Alkharusi, H.; Aldhafri, S.; Kazem, A.; Alzubiadi, A.; Al-Bahrani, M. Development and validation of a short version of the Parental Authority Questionnaire. Soc. Behav. Personal. 2011, 39, 1193-1208. [CrossRef]

72. Tabachnick, B.G.; Fidell, L.S. Using Multivariate Statistics, 4th ed.; Allyn and Bacon: Boston, MA, USA, 2001.

73. Pallant, J. A Step by Step Guide to Data Analysis Using the SPSS Program: Survival Manual, 4th ed.; Allen and Unwin Book Publishers: Crows Nest, Australia, 2010.

74. Aldhafri, S.; Alkharusi, H.; Alrajhi, M.; Alnabhani, H.; Alkalbani, M. Omani students' academic efficacy beliefs in relation to their extrinsic and intrinsic motivation to learn English. In Proceedings of the DU National English Language Conference: Innovation in Teaching and Researching English Language, Linguistics, Literature and Translation: Voices from the Omani Classroom, Dhofar, Dhofar University, Salalah, Oman, 22-24 February 2014.

75. Alkharusi, H.; Aldhafri, S.; Alnabhani, H.; Alkalbani, M. Classroom assessment: Teacher practices, student perceptions, and academic self-efficacy beliefs. Soc. Behav. Personal. Int. J. 2014, 42, 835-855. [CrossRef]

76. Alhadabi, A.; Karpinski, A.C. Grit, self-efficacy, achievement orientation goals, and academic performance in University students. Int. J. Adolesc. Youth 2020, 25, 519-535. [CrossRef]

77. Aldhafri, S. The relationship between students' perceptions of parenting styles and their university life adjustment. J. Educ. Psychol. Stud. 2016, 10, 687-696. [CrossRef]

78. Aldhafri, S.; Kazem, A.; Alzubiadi, A.; Yousif, Y.; Al-Bahrani, M.; Alkharusi, H. Parenting styles as perceived by Omani children (classes 7 to 12) and their relationships with some demographic variables. Int. J. Res. Educ. 2011, 29, 1-26.

79. Al Rub, A.; Majedh, F. Parenting Styles Used with Preschool Children among Arab Immigrant Parents in a US Context. Ph.D. Thesis, Colorado State University Libraries, Fort Collins, CO, USA, 2013.

80. Dwairy, M.; Achoui, M.; Abouserie, R.; Farah, A.; Sakhleh, A.A.; Fayad, M.; Khan, H.K. Parenting styles in Arab societies: A first cross-regional research study. J. Cross-Cult. Psychol. 2006, 37, 230-247. [CrossRef]

81. Conrade, G.; Ho, R. Differential parenting styles for fathers and mothers. Aust. J. Psychol. 2001, 53, $29-35$. [CrossRef]

82. Russell, A.; Aloa, V.; Feder, T.; Glover, A.; Miller, H.; Palmer, G. Sex-based differences in parenting styles in a sample with preschool children. Aust. J. Psychol. 1998, 50, 89-99. [CrossRef]

83. Winsler, A.; Madigan, A.; Aquilino, S. Correspondence between maternal and paternal parenting styles in early childhood. Early Child. Res. Q. 2005, 20, 1-12. [CrossRef] 
84. Martinez, I.; Garcia, F.; Veiga, F.; Garcia, O.F.; Rodrigues, Y.; Serra, E. Parenting styles, internalization of values and self-esteem: A cross-cultural study in Spain, Portugal and Brazil. Int. J. Environ. Res. Public Health 2020, 17, 2370. [CrossRef] [PubMed]

85. Dwairy, M. Parenting styles and psychological adjustment of Arab adolescents. Transcult. Psychiatry 2004, 41, 233-252. [CrossRef] [PubMed]

86. Dwairy, M.; Achoui, M.; Filus, A.; Rezvan nia, P.; Casullo, M.M.; Vohra, N. Parenting, mental health and culture: A fifth cross-cultural research on parenting and psychological adjustment of children. J. Child Fam. Stud. 2010, 19, 36-41. [CrossRef]

87. Keshavarz, S.; Mounts, N.S. Perceived parenting style of fathers and Iranian adolescents' self-efficacy: The moderating role of gender and education. J. Genet. Psychol. 2017, 178, 281-290. [CrossRef]

88. Steinberg, L.; Mounts, N.; Lamborn, S.; Dornbusch, S. Authoritative parenting and adolescent adjustment across varied ecological niches. J. Res. Adolesc. 1991, 1, 19-36.

89. Cohen, D.A.; Rice, J. Parenting styles, adolescent substance use, and academic achievement. J. Drug Educ. 1997, 27, 199-211. [CrossRef]

90. Kaisa, A.; Hakan, S.; Jari-Erik, N. Parenting styles and adolescents' achievement strategies. J. Adolesc. 2000, 23, 205-222.

91. Martínez, I.; García, J.F. Impact of parenting styles on adolescents' self-esteem and internalization of values in Spain. Span. J. Psychol. 2007, 10, 338-348. [CrossRef]

92. Dwairy, M.; Achoui, M. Parental control: A second cross-cultural research on parenting and psychological adjustment of children. J. Child Fam. Stud. 2010, 19, 16-22. [CrossRef]

(C) 2020 by the authors. Licensee MDPI, Basel, Switzerland. This article is an open access article distributed under the terms and conditions of the Creative Commons Attribution (CC BY) license (http://creativecommons.org/licenses/by/4.0/). 